\title{
AGING AND ITS IMPACT ON THE QUALITY OF GRAFTS: an experimental study in rats livers
}

\author{
Stela Maria MOTA ${ }^{1}$, Glauber GASPERIN², Carlos Thadeu CERSKI ${ }^{3}$, \\ Jarbas Rodrigues de OLIVEIRA ${ }^{4}$ and Mário Reis ÁLVARES-da-SILVA ${ }^{5}$
}

\begin{abstract}
Context - There are consistent clues of worse results with grafts from older donors, especially in hepatitis C. University of Wisconsin (UW) solution is adopted for liver preservation, but other solutions are being studied, as fructose-1,6-bisphosphate (FBP). Objective - To determinate the impact of aging of the donor on the cold ischemia injury in rat livers and compare UW and FBP. Methods - Twenty male Wistar rats were studied - 10, aging 20 weeks: 5 to preservation with UW (C-UW) and 5, FBP (C-FBP); and other 10, aging 50 weeks: 5 to UW (E-UW) and 5 to FBP (E-FBP). Rats were anesthesized, submitted to hepatectomy, and graft was kept under $2-4^{\circ} \mathrm{C}$ for 8 hours. Liquid samples were taken at 2, 4, 6, and 8 hours, to determine AST and LDH. At the end, in the liver tissue thiobarbituric acid reactive substances and catalase were determined. Results - Average liver weight was similar between controls and the others $(12.5 \mathrm{~g} \pm 1.8$ and $13.4 \mathrm{~g} \pm 2.0)$. AST and LDH levels were higher in C-UW group $(P<0.05)$. In the older group, there was a difference between UW and FBP preserved livers related to LDH, but not to AST. Thiobarbituric acid reactive substances were superior in control group than in the older one $(P=0.001)$. Catalase activity was similar between these groups $(P$ $=0.11)$, but it was superior in UW preserved animals $(P=0.02)$. Conclusion - Livers from older rats were similar to the controls regarding cold ischemia injury in FBP group. Surprisingly, with UW solution there was less cold ischemia injury in the elderly group. When comparing both solutions, FBP provided significantly more protection than UW in the controls. There was a trend to FBP to being better than UW in the elderly group. Further studies with liver from older donors and ischemia and reperfusion are needed.

HEADINGS - Aging. Liver transplantation. Tissue donors. Rats.
\end{abstract}

\section{INTRODUCTION}

Liver transplantation (LT) is currently the treatment of choice for end-stage both chronic and acute hepatic diseases $^{(7)}$. As better are the results, more patients are considered to be listed ${ }^{(5)}$, and besides donor shortage, this is the cause of the increases of waiting rolls and, consequently, increasing of mortality in list ${ }^{(18)}$.

Donor shortage has made transplant groups to expand their limits for acceptation of organs ${ }^{(4,15)}$. Age of donors has been usually considered a limiting factor. Some of the groups reject grafts from donors which are older than 60 or 65 years-old ${ }^{(6,10,20)}$. However, these data are matter of controversy. Regarding liver function, bilirubins and aminotransferases are kept under normal values even in individuals with extremes of age, but serum albumin levels use to decline as years go by, suggesting damage on the protein synthesis ${ }^{(9)}$.

The most common disease that leads to LT is cirrhosis due to hepatitis $\mathrm{C}$ virus (HCV). There are consistent clues of worse results with grafts from older donors in these recipients, with earlier recurrence of $\mathrm{HCV}$, and lower survival both of the graft and the patient. The use of those organs has been often unadvised in HCV recipients ${ }^{(14,16)}$.

University of Wisconsin (UW) solution is now adopted by the most of the liver transplant teams ${ }^{(13)}$. Its costs, and evidences of non-universal protection, as seen by primary non-function rates ${ }^{(19)}$, make attempts to research of others solutions, as Celsior and HTK ones $^{(12)}$. In this way, fructose-1,6-bisphosphate (FBP) may have some utility. It is an energetic mediator of glycolytic route, which has been studied in the field of cell protection in many pathological situations, as sepsis, and ischemia/reperfusion in organs other than the liver ${ }^{(11)}$.

The aim of this study was to determinate the impact of the aging of the donor on the cold ischemia injury (COI) in rat livers, as well to compare two distinct solutions of preservation: UW and FBP.

\footnotetext{
Research supported by Fundo de Incentivo à Pesquisa e Eventos - Hospital de Clínicas de Porto Alegre and CAPES Foundation, Ministry of Education, Brazil

Programa de Pós-graduação - Gastroenterologia Universidade Federal do Rio Grande do Sul - UFRGS. ${ }^{2}$ Faculdade de Medicina - UFRGS; ${ }^{3}$ Departamento de Patologia

- UFRGS; ${ }^{4}$ Laboratório de Biofísica, Pontifícia Universidade Católica do Rio Grande do Sul; ${ }^{5}$ Departamento de Medicina Interna (Gastro-Hepatologia) - UFRGS, Porto Alegre, RS, Brasil.

Correspondence: Dr. Stela Mota - Rua Pinheiro Machado, 2380/305-A - 97050-600 - Santa Maria, RS, Brasil. E-mail: smmota@terra.com.br
} 


\section{METHODS}

All the procedures were carried out according to the current legislation in Brazil, and the study was approved by Ethics and Research Committee of Hospital de Clínicas, Porto Alegre, RS, Brazil. Twenty adult male Wistar rats were studied, settled down separately in living-boxes of transparent polycarbonate, submitted to clear-and-dark cycles of 12 hours, under controlled temperature $\left(22^{\circ} \mathrm{C}\right)$. The animals were fed with regular diet and received water ad libitum.

Animals were divided into two groups: control group: 10 rats, aging 20 weeks, randomly assigned 5 to preservation with UW (C-UW) and 5, FBP (C-FBP); and older group: 10 rats, aging 50 weeks, randomly assigned to same way: 5 to UW (I-UW) and 5 to FBP (I-FBP). So, there were 4 subgroups of animals that were studied.

Rats were anesthesized through isofluorane 1,5\% (Isofluorano ${ }^{\circledR}$, Abbott), using calibrated vaporizator. Later, they were submitted to laparotomy, and portal vein was cannulated by an intravenous catheter of $20 \mathrm{G}$ (Abbocath ${ }^{\circledR}$, n. 20 Johnson \& Johnson), and connected to $125 \mathrm{~mL}$ of $4^{\circ} \mathrm{C}$ preservation solution, according to the group: UW (Viaspan ${ }^{\circledR}$ ) or FBP saline solution at 10 $\mathrm{mmol} / \mathrm{L}$, under a pressure of $60 \mathrm{cmH} 2 \mathrm{O}$. Finally, hepatectomy was performed, and the liver was preserved at $50 \mathrm{~mL}$ of the respective solution, kept under $2-4^{\circ} \mathrm{C}$ for 8 hours, during which were taken out liquid samples at 2, 4, 6, and 8 hours.

Animals were weighed on digital scale (Marte, model AS5500c) very before the surgical procedure, as well were the livers at the end of the period of preservation. Serum glucose and albumin were carried out through the kinetic method UV (Hitachi 917, Roche). From the samples taken were determined aspartato-aminotransferase (AST) and lactic dehidrogenase (LDH) - (kinetic method UV, Hitachi 917-Roche).

At the end of the preservation period, thiobarbituric acid reactive substances (TBARS), and catalase activity were determined. TBARS was done through the technique described by Halliwell and Guteridge ${ }^{(8)}$, and catalase by the reaction among phosphate buffer $50 \mathrm{mH}$ and hydrogen peroxide $0,3 \mathrm{M}$, in the homogenized of hepatic tissue, with reading effected at the spectrophotometer of $240 \mathrm{~nm}$.

The specimens were stained with hematoxilin and eosin, observed by a single and blinded pathologist, who examined coded samples of tissue. Portal inflammatory infiltrate, pericentral ischemic necrosis and periductal fibrosis, as well as steatosis, were analyzed.

The test of normality of Kolmogorov-Smirnov was applied to all variables. In comparing the variables of unique measure one-way ANOVA was employed, followed by the test of multiple comparisons of Duncan. The data of serial measures were transformed in ranks, except TBARS and catalasis, and compared through ANOVA, followed by the test of minimal differences. Significance level for $\alpha$ was 0.05 .

\section{RESULTS}

The average body weight of the animals from the control group and the older one was respectively $357.7 \mathrm{~g} \pm 22.23$ and
$425.2 \mathrm{~g} \pm 23.42-P<0.001$. There was no difference between the average liver weight between both groups $(12.51 \mathrm{~g} \pm 1.8$ and $13.45 \mathrm{~g} \pm 2.0$, respectively). Regarding blood glucose levels, there was no difference between the groups (226.9 g/ $\mathrm{dL} \pm 47.22$ and $179.3 \pm 76.25)$. Albumin was higher in the older group $(2.59 \mathrm{mg} / \mathrm{dL} \pm 0.48$ and $3.04 \mathrm{mg} / \mathrm{dL} \pm 0.53)$, but there were no significant difference $(P=0.063)$.

When compared to the biochemical parameters of preservation, there was significant difference between AST and LDH median levels. Both the parameters were superior in samples taken from the control group preserved with UW in relation to the other three subgroups $(P<0.05)$. Regarding the older group, there was a difference between UW and FBP preserved livers related to LDH, but not to AST. The results are shown in Figures 1 and 2.

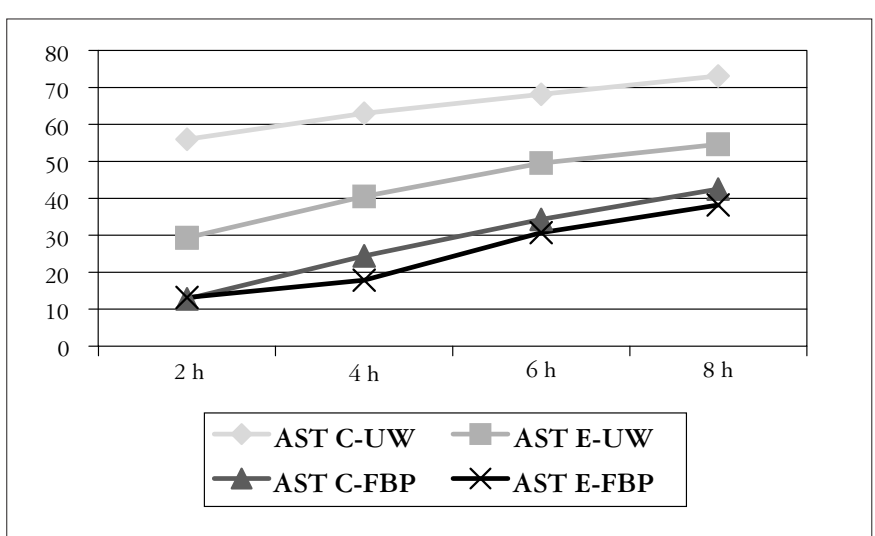

FIGURE 1. Here are presented the results obtained with AST and their comparison between the different groups. AST = aspartate-aminotransferase $(\mathrm{UI} / \mathrm{L}) . \mathrm{C}-\mathrm{UW}=$ control animals, preserved with $\mathrm{UW}, \mathrm{C}-\mathrm{FBP}=$ control animals, preserved with FBP, E-UW = elderly animals, preserved with UW, E-FBP= elderly animals, preserved with FBP. C-UW x E-UW $=P=0.033^{*}$; C-UW x C-FBP $=P=0.001 *$ C-UW x E-FBP $=P=0.001 *$ E-UW $\times$ C-FBP $=P=0.126 ; \mathrm{E}-\mathrm{UW} \times \mathrm{E}-\mathrm{FBP}=P=0.063 ; \mathrm{C}-\mathrm{FBP} \times \mathrm{E}-\mathrm{FBP}=P=0.709$

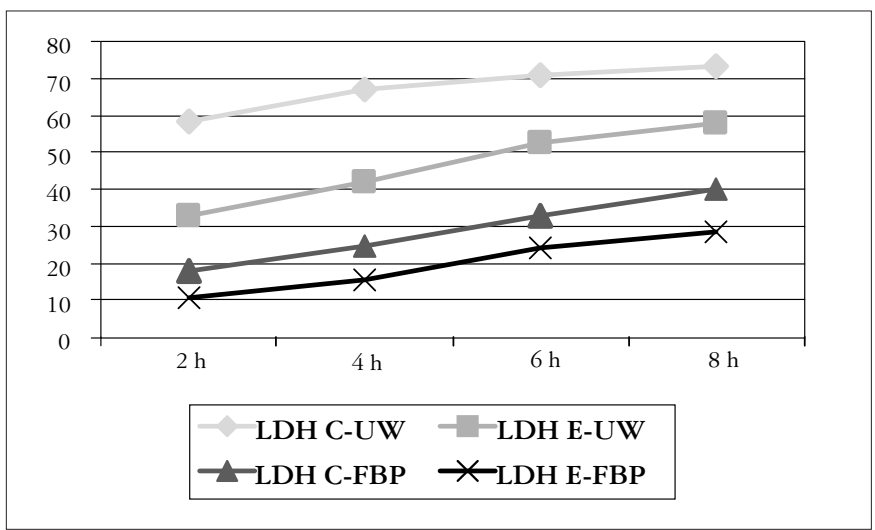

FIGURE 2. Here are presented the results obtained with LDH and their comparison between the different groups. $\mathrm{LDH}=$ lactate desidrogenase $(\mathrm{UI} / \mathrm{L})$. $\mathrm{C}-\mathrm{UW}=$ control animals, preserved with UW, C-FBP $=$ control animals, preserved with FBP, E-UW = elderly animals, preserved with UW, E-FBP= elderly animals, preserved with FBP. C-UW x E-UW $=P=0.018^{*}$; C-UW x C-FBP $=P=0.0001 *$ C-UW $\times$ E-FBP $=P=0.0001 * ; \mathrm{E}-\mathrm{UW} \times \mathrm{C}-\mathrm{FBP}$ $=P=0.044^{*} ; \mathrm{E}-\mathrm{UW} \times \mathrm{E}-\mathrm{FBP}=\mathrm{P}=0.004^{*} ; \mathrm{C}-\mathrm{FBP} \times \mathrm{E}-\mathrm{FBP}=P=0.267$ 
TBARS were superior in control group than in the older one $(4.14 \mathrm{nmol} / \mathrm{g}$ tissue \pm 0.79 vs $2.72 \pm 0.85)-P=0.001$, but there was no difference between the preservation solutions (UW: $3.45 \pm 1.45$ vs FBP $3.48 \pm 0.48-P=0.94$ ). Catalase activity was similar between the both groups - control and older $(92.1 \mathrm{mmol} / \mathrm{min} / \mathrm{mg}$ protein \pm 47.1 vs $65.4 \pm 19.4)-P$ $=0.11$, but it was superior in UW preserved animals $(98.7$ \pm 43.2 vs $58.8 \pm 15.6)-P=0.02$.

Mild centrolobular ischemic injury was found in four livers of the control group and in two of the older ones. In this group, two animals have had mild portal inflammatory changes. No animal had steatosis.

\section{DISCUSSION}

Nowadays, efforts to improve the quality of graft and its preservation still represent an important field of research. In this study, it was just evaluated cold ischemia injury COI, since our focus was the aging donor. If reperfusion would have been done, certainly it would be added other independent variables. Cold preservation was done during 8 hours. Maybe, that time can be questioned, since UW solution would guarantee organ viability for 24 hours. Indeed, that extended time is not often used, since more than 12 hours carries high risk of injury, mainly of biliary cells ${ }^{(1,3)}$. Moreover, in a previous study, 12 hours of cold preservation were enough to demonstrate any injury ${ }^{(11)}$. In this context, defining old rats seems essential. Animals used in this study were older than 50 weeks, and it is consistent with many specific references regarding aging of rats ${ }^{(9,2)}$. There are structural changes that use to occur in older rats, like hepatocyte and nuclei enlargement ${ }^{(9,17)}$. Furthermore, those changes continue after LT, even when the receptor is young ${ }^{(9)}$.
The weight of the livers of the studied animals did not differ among the groups. In the same way, blood glucose was not different among them. Regarding to COI, AST, and also $\mathrm{LDH}$, were higher in UW control group, when compared to the others. When considered the older group, AST and $\mathrm{LDH}$ were higher in livers from the UW-preserved livers in comparison to the FBP-preserved. Indeed, this difference was significant regarding LDH. It seems that FBP could exert some protective effects on grafts from older donors. Moresco et al. ${ }^{(11)}$ had demonstrated that FBP is able to reduce COI injury when compared to UW solution in normal fed young rats. So, our results were quite similar with their. Unfortunately there is no other published paper focusing $\mathrm{COI}$ in older rats to allow a comparison with our results.

When oxidative stress was evaluated, TBARS levels were superior in control animals, suggesting bigger injury that was not solution-dependent.

Catalasis activity was similar among both older and control ones, but its levels were higher in UW preserved groups. As catalasis is released in order to counterpoint the harmful effects of the oxidative stress, it is possible that more pronounced tissue damage have occurred with FBP than with UW.

In summary, there was not more pronounced ischemic injury in preserved livers from older rats when compared to the controls in FBP group. By the other hand, when considered UW solution, biochemical and lipoperoxidation injury were worse in the control ones than in the olders. It is possible to conclude that livers from older donors are similar to the younger ones, but it is not the same that is currently described after LT in humans. Maybe, in this scenario, reperfusion could be the main source of injury. Further studies with liver from older donors and ischemia and reperfusion are needed.

Mota SM, Gasperin G, Cerski CT, Oliveira JR, Álvares-da-Silva MR. O impacto do envelhecimento na qualidade do enxerto: estudo experimental em fígados de ratos. Arq Gastroenterol. 2010;47(3)297-300.

RESUMO - Contexto - Dados da literatura atual sugerem piores resultados quando os transplantes hepáticos são realizados com enxertos provenientes de doadores idosos. O uso da solução Universidade de Wisconsin (UW) é universal; entretanto alternativas como a fructose-1,6-bisfosfato (FBP) vêm sendo estudadas. Objetivos - Determinar o impacto do envelhecimento do doador no dano de isquemia a frio em fígados de ratos, comparando as soluções de FBP e UW. Métodos - Vinte ratos Wistar foram estudados - 10 com 20 semanas: 5 preservados com UW (C-UW) e 5 com FBP (C-FBP); e outros 10, com 50 semanas: 5 com UW (E-UW) e 5 com FBP (E-FBP). A preservação durou 8 horas. Foram dosadas AST e LDH nas alíquotas do líquido de preservação a cada 2 horas. Resultados - Os níveis de AST e LDH foram superiores no grupo (C-UW) ( $P<0.05)$. Quando comparadas UW x FBP no grupo de idosos houve diferença quanto à LDH, mas não com a AST. Conclusão - A preservação dos fígados de ratos idosos foi similar aos dos controles, quando preservados com FBP. Quando utilizada UW, a lesão de preservação foi menor no grupo de ratos idosos. A FBP minimizou a isquemia a frio nos controles, quando comparada a UW. Houve tendência de a FBP ser superior a UW no grupo idosos.

DESCRITORES - Envelhecimento. Transplante de fígado. Doadores de tecidos. Ratos.

\section{REFERENCES}

1. Almada LA, Scandizzi AL, Guibert EE, Furno G, Rodríguez JV. Biliary inorganic phosphate as a tool for assessing cold preservation-reperfusion injury: a study in the isolated perfused rat liver model. Liver Transpl. 2003;9:160-9.

2. Baker H, Lindseu J, Weibroth S. The laboratory rat. New York: Academic Press; 1979.
3. Carrasco L, Sanchez-Bueno F, Sola J, Ruiz JM, Ramirez P, Robles R, Rodriguez JM, Parrilla P. Effects of cold ischemia time on the graft after orthotopic liver transplantation. A bile cytological study. Transplantation. 1996,61:393-6.

4. Chang AJ, Dixit V, Saab S. Fulminant hepatic failure. Curr Treat Options Gastroenterol. 2003;6:473-9.

5. Dickson ER. Liver transplantation for primary sclerosing cholangitis: impact of risk factors on outcome. Liver Transpl Surg. 1996;2:99-108. 
6. Emre S, Schwartz ME, Altaca G, Sethi P, Fiel MI, Guy SR, Kelly DM, Sebastian A, Fisher A, Eickmeyer D, Sheiner PA, Miller CM. Safe use of hepatic allografts from donors older than 70 years. Transplantation. 1996;62:62-5.

7. Everson GT, Trotter J. Role of adult living donor liver transplantation in patients with hepatitis C. Liver Transpl. 2003;9:s64-s8.

8. Gutteridge JM, Halliwell B. Iron toxicity and oxygen radicals. Baillieres. Clin Hematol. 1989;2:195-256.

9. Koh M, Okamoto E, Yamanaka J, Fujimoto J. Impact of donor age on the growth of young recipient rats after liver transplantation. Surg Today. 2006;36:457-66.

10. Marino IR, Doyle HR, Aldrighetti L, Doria C, McMichael J, Gayowski T, Funf JJ, Tzakis AG, Starzl TE. Effect of donor age and sex on the outcome of liver transplantation. Hepatology. 1995;22:1754-62.

11. Moresco RN, Santos RC, Alves Filho JC, Cunha AA, Dos Reis C, Reichel CL, De Oliveira JR. Protective effect of fructose-1,6-bisphosphate in the cold storage solution for liver preservation in rat hepatic transplantation. Transplant Proc. 2004;36:1261-4

12. Nardo B, Beltempo P, Bertelli R, Montalti R, Vivarelli M, Urbani L, Masetti M, Di Naro A, Filipponi F, Mosca F, Pinna A, Cavallari A. Comparison of Celsior and University of Wisconsin in cold preservation of liver from octagenarian donors. Transplant Proc. 2004;36:523-4.

13. Nardo B, Montalti R, Beltempo P, Bertelli R, Puviani L, Pacilè V, Vivarelli M, Cavallari A. Octogenarian livers successfully transplanted in patients with fulminant hepatic failure. Transplant Proc. 2005;37:389-91
14. Pirenne J, Monbaliu D, Van Gelder F, Van Hees D, Aerts R, Verslype C, Van Steenbergen W, Ferdinande P, Fevery J, Nevens F, Coosemans W, Stockman W, Lormans P. Liver transplantation using livers from septuagenarian and octogenarian donors: an underused strategy to reduce mortality on the waiting list. Transplant Proc. 2005;37:1180-1.

15. Pokorny H, Langer F, Herkner H, Schemberger R, Plöchl W, Soliman T, Steininger $\mathrm{R}$, Muehlbacher F. Influence or cumulative number of marginal donor criteria on primary organ dysfunction in liver recipients. Clin Transplant. 2005;19:532-6.

16. Russo M W, Galanko J A, Zacks S L, Beavers K L, Fried M W, Shrestha R Impact of donor age and year of transplant recipients with chronic hepatitis $\mathrm{C}$. Am J Transplant. 2004;4:1133-8.

17. Stupina AS, Berezhkov NV. Morphological manifestations of compensatoryadaptive processes in the liver during aging. Biull Eksp Biol Med. 1988;105:380-2.

18. United Network for Organ Sharing. Richmond, Virginia Disponível em: http:// www.unos.org. Último acesso: julho de 2006.

19. Upadhya GA, Strasberg SM. Glutathione, lactobionate, and histidine cryptic inhibitor of matrix metalloproteinases contained in University of Wisconsin and histidine/ tryptophan/ketoglutarate liver preservation solutions. Hepatology. 2000;31:1115-22.

20. Wall WJ, Mimeault R, Grant DR, Bloch M. The use o folder donor livers for hepatic transplantation. Transplantation. 1990;49:377-81.

Received 3/5/2008 Accepted 12/8/2009 